\title{
Restauração do Sistema de Organização
}

D entre as recentes iniciativas de irrecuzável interêsse para a administração, por isso que possibilita aperfeiçoar o mecanismo administrativo, mediante a reforma dos diversos serviços, a racionalização dos métodos e rotinas de trabalho, merece especial registro a restauração do sistema de organização, aplicável aos Ministérios Civis.

Uma recapitulação, mesmo perfunctória, melhor esclarecerá a importância da matéria. Como é oportuno lembrar. desde a Lei n. 284, instituira-se, ao lado do sistema do Pessoal, de Material e de Orçamento, uma quarta área de atividades-meio por assim dizer conexa com as três anteriores: o sistema de organizaçâo. Tinha êste como finalidade pre. cipua estudar a estrutura e o funcionamento dos servicos em geral a fim de recomendar ao Govêrno as medidas necessárias ao respectivo aperfeiçoamento. Implícito estava aí o exame de planos de racionalização de serviços públicos, de normas de trabalho, de propostas de fusão e supressão de órgãos administrativos com o objetivo de eliminar displicidades de competência e atribuições.

Para fazer funcionar tal sistema é que a Lei n. 28/ criara as Comissões de Eficiência junto a cada Ministério, e articuladas com o antigo Conselho Federal do Serviço Público Civil. Instituido o D.A.S.P., fortalecera-se o aparetho de organização, com a existência de uma Divisão especializada - a Divisão de Organização e Coordenação do D.A.S.P. - à qual deveria competir "o estudo, orientação e supervisão do levantamento geral das condiçoes de funcionamento dos serviços públicos", e da implantacão de métodos de trabalho.

De 1938 a 1945, funcionava, assim, um sistema de organização, que, apesar das insuficiências inerentes a uma 
fase experimental de atividade, prestou à administração pública assinalados serviços, conforme se pode verificar à leitura dos Relatórios do D.A.S.P., referentes àquele periodo.

Infelizmente, porém, a reforma imposta ao D.A.S.P. pelo Decreto-lei n. ${ }^{\circ}$ 8.323-A extinguiu o órgão central, coordenador do sistema, desarticulando, na esfera da administração federal, as atividades de organização e métodos de trabalho. Era o retrocesso à situação anterior à Lei n.o 284. A mesma reforma, que pràticamente destruíra o Sistema de Material, igualmente amputava o Sistema de Organização, exatamente numa época em que paises de administra. ção altamente progressista, como os Estados Unidos, a Inglaterra e a França têm procurado ampliar e fortalecer as atividades de organização e métodos, já familiarmente conhecidas pela sigla $O . M$.

Como salientou recentemente o D.A.S.P. na Exposição de Motivos em que justificou a expedição de Regimento Padrão das Seções de Organização, a eliminação do sistema de Organização, ocorrera paradoxalmente quando "já se fazia sentir a necessidade de uma reforma administrativa geral, para cuja execução seria necessário recorrer aos órgãos técnicos em matéria de organização".

Se a extinção do sistema foi uma das aberrações da reforma de 1945, sua restauração constituiu o grande acontecimento de ordem administrativa. E aqui reside o mérito da Lei n.o 1.650, de 19 de julho de 1952, que, criando as Seções de Organização dos Ministérios Civis, reparou o êrro do Decreto-lei n. 8.323-A.

Mas, sancionada a lei, restava ainda dar a real estrutura do sistema, em sua nova fase. À atual direção-geral do D.A.S.P. coube realizar tal complementação, encaminhando ao Senhor Presidente da República o Projeto de que resultou o Decreto $n$. $^{3} 36.75 \%$, de 7 de janeiro de 1955 , aprovando o Regimento padrão das Seções de Organização dos Ministérios Civis. Novo estágio se abre, na administração, às atividades de organização e métodos, não se devendo poupar votos no sentido de que o êxito da reestruturação, ora ultimada, do sistema, seja seguido do êxito de sell funcionamento. 